\title{
Fair Trade Towns USA: growing the market within a diverse economy
}

\author{
Sarah Lyon $^{1}$ \\ University of Kentucky, USA
}

\begin{abstract}
Fair trade is both a movement and a market, and the tension between these two domains reflects an ambiguity at the center of fair trade in the United States, resulting from long-standing debates within the contemporary movement. In practice, this ideological division produces a struggle between companies that offer a small number of fair trade products aside a vast number of conventional items, and those that sell only fair trade certified products. However, it also shapes the experience of on-the-ground fair trade advocacy work. This article uses Gibson-Graham's diverse economies framework to explore three arenas in which this is most clearly evidenced. First, some fair trade advocates are wary of Fair Trade USA's (FTUSA) power and strategies. They are aware that multiple fair trade certification frameworks currently exist; however they aren't always sure which ones are most desirable and why. This confusion can be problematic in Fair Trade Towns (FTT) advocacy work which involves convincing community members, institutions and governments to purchase more fair trade products. Second, in light of FTUSA's strategic marketization of fair trade and the entry of large corporate players into the U.S. fair trade market, fair trade advocates increasingly find themselves in the equivocal position of providing free labor and marketing for large corporations. Third, the efforts of some FTT advocates are stymied by the determined localvores in their community who are more focused on minimizing carbon footprints and supporting local farmers than promoting social justice and environmental stewardship in the developing world. These tensions raise important questions about the scalar politics of alternative markets and diverse economies.
\end{abstract}

Keywords: fair trade, social movements, localism, ethical consumption, Gibson-Graham

\section{Résumé}

Le commerce équitable est à la fois un mouvement et un marché. La tension entre ces deux domaines reflète une ambiguïté au centre du commerce équitable aux États-Unis, résultant de longs débats au sein du mouvement contemporain. Dans la pratique, cette division idéologique conduit à une lutte entre les entreprises qui offrent un petit nombre de produits du commerce équitable ainsi que d'un grand nombre d'éléments classiques, et ceux qui ne vendent que des produits certifiés équitables. Cependant, il façonne aussi l'expérience du travail sur le terrain plaidoyer du commerce équitable. Cet article utilise le cadre des économies diversifiée de Gibson-Graham à explorer trois domaines dans lesquels cela est plus clairement mise en évidence. Tout d'abord, certains défenseurs du commerce équitable se méfient de la puissance et des stratégies de FTUSA (Fair Trade USA). Ils sont conscients que plusieurs cadres de certification du commerce équitable existent actuellement, mais ils ne savent pas toujours quels sont ceux qui sont les plus souhaitables et pourquoi. Cette confusion peut être problématique dans des villes équitables (TTF) ou le travail consiste à convaincre les membres de la communauté, les institutions et les gouvernements à acheter des produits plus équitables. Deuxièmement, à la lumière de la marchandisation stratégique FTUSA du commerce équitable et de l'entrée des grands acteurs de l'entreprise sur le marché du commerce équitable Etats-Unis, les défenseurs du commerce équitable se trouvent de plus en plus dans la position équivoque de fournir le travail libre et le marketing pour les grandes entreprises. Troisièmement, les efforts de certains défenseurs de la TTF sont entravés par les Localvores dans leur communauté qui sont plus axés sur la réduction de l'empreinte carbone. Ils soutenir les agriculteurs locaux plutôt que de promouvoir la justice sociale et la gérance de l'environnement dans le monde en développement. Ces tensions soulèvent d'importantes questions sur la politique scalaires de marchés alternatifs et diverses économies.

Mots-clés: commerce équitable, les mouvements sociaux, le localisme, la consommation éthique, GibsonGraham

\footnotetext{
${ }^{1}$ Dr. Sarah Lyon, Associate Professor of Anthropology, University of Kentucky, Lexington, KY, USA. Email: sarah.lyon "at" uky.edu. Generous support for this research was provided by a University of Kentucky Special Summer Faculty Research Award and a Sabbatical Research Award. I would like to thank Brian Burke, Boone Shear, the journal editors and an anonymous reviewer for their helpful editorial suggestions which significantly shaped the final version of this article. This is the second paper in Burke, B.J. and B.W. Shear (eds.) 2014. "Non-capitalist political ecologies", special section of the Journal of Political Ecology 21: 127-221.
} 


\section{Resumen}

Comercio justo es al mismo tiempo un movimiento y un mercado, y la tensión entre estos dos dominios refleja una ambigüedad en el centro del comercio justo en los Estados Unidos, como resultado de largos debates dentro del movimiento contemporáneo. En la práctica, esta división ideológica produce una lucha entre compañías que ofrecen un pequeño número de productos de comercio justo al lado de un vasto número de ítems convencionales y aquellos que venden solamente productos certificados de comercio justo. Sin embargo, esto también hace parte de la experiencia en-el-terreno por la defensa del comercio justo y este artículo usa el marco de diversas economías de Gibson-Graham para explorar tres arenas en las cuales este se evidencia más claramente. Primero, algunos defensores del comercio justo son cautelosos del poder y las estrategias del FTUSA (Fair Trade USA). Ellos son conscientes que múltiples marcos de certificación de comercio justo existen; sin embargo, ellos no están siempre seguros acerca de cuáles son los más apropiados y por qué. Esta confusión puede ser problemática en el trabajo por la defensa del Fair Trade Towns (FTT) que requiere el convencimiento de miembros de la comunidad, instituciones y gobiernos para adquirir más productos de comercio justo. Segundo, a la luz de la marquetización estratégica de comercio justo del FTUSA y la entrada de grandes actores corporativos en el mercado del comercio justo en los Estados Unidos, defensores del comercio justo se encuentran cada vez más a ellos mismos en la posición equivocada de proveer mano de obra y mercadeo gratis a corporaciones grandes. Tercero, los esfuerzos de algunos defensores de las FTT son obstruidos por los determinados localvores en su comunidad quienes están más enfocados en minimizar huellas de carbono y apoyar agricultores locales que en promocionar justicia social y cuidado del medio ambiente en el mundo en desarrollo. Estas tensiones elevan preguntas importantes acerca de políticas escalares de mercados alternativos y economías diversas.

Palabras clave: comercio justo, movimientos sociales, localismo, consumo ético, Gibson-Graham

\section{Introduction}

Two hours into our interview in June 2011 Sylvia, a fair trade activist in Vermont, asked, "Look, can I show you something that will explain what I'm talking about?" She got up from the loveseat she was sitting on, waved me over to her home computer, and quickly opened up the Fair Trade USA website. "I'm so mad about this," she said:

You know I have some doubts about the direction the organization is going in, like I said, focusing more on making money than helping farmers. So, a couple of months ago I tried to do some research on their financials. I clicked on this link here that's supposed to bring up their financial information and nothing happened. It's a non-profit organization-they're supposed to provide their financial statements to the public but they're not here! I immediately e-mailed the CEO and COO to complain. They seemed kind of annoyed but they promised they would fix the broken links and post the information. But this was months ago! It's still not here.

To Sylvia, this lack of transparency was symptomatic of the asymmetrical power relations characterizing some channels of the fair trade movement in the United States and Fair Trade USA's increasingly business oriented outlook.

This conversation turned out to be a harbinger of things to come as Fair Trade USA (FTUSA), the agency responsible for certifying products carrying the fair trade mark in the United States, announced its split from the Fair Trade Labeling Organizations International in October 2011. The World Fair Trade Organization's response to this decision is representative of the criticism FTUSA received at the hands of student activists and others who question the organization's market expansion strategy. In a press release ${ }^{2}$ the group declared that:

\footnotetext{
${ }^{2}$ http://www.wfto.com/index.php?option=com_content\&task=view\&id=1574\&Itemid=314 (accessed 3/27/2012).
} 
...we see little evidence of dialogue, transparency or respect (key aspects that define Fair Trade) in the unilateral decision of Fair Trade USA to widen the scope of Fair Trade in ways that will surely negatively impact those currently involved. This action seems more to satisfy and enrich the very people whose actions caused Fair Trade to be established in the first place at the expense of the small farmer.

FTUSA's CEO of course doesn't see it that way. In a conference call with fair trade advocates shortly after the decision was announced Paul Rice argued, "Historically, so many folks in the movement saw fair trade as a partnership between producers in the developing world and consumers in the global north. Companies were kind of a necessary evil to make that partnership possible." After 13 years of partnership with FLO, Fair Trade USA is breaking away in order to "make business-friendly decisions and double U.S. fair-trade sales by 2015." ${ }^{3}$ Clearly the patina of fair trade paradise, in which happy, dark-skinned farmers supply discerning, white consumers with ethical products (Varul 2009; Wright and Heaton 2006), has lost a bit of its shine in the wake of this controversial decision. In step with its goal of doubling fair trade sales by 2015 by creating an energized and business friendly climate, FTUSA is now attempting to brand and direct the fair trade consumer movement in the United States by claiming symbolic ownership of grassroots efforts to promote fair trade through its sponsorship of Fair Trade Towns and Fair Trade Universities campaigns. The effort is supported by a US\$300,000 grant from Green Mountain Coffee Roasters, the largest fair trade coffee roaster in the United States, in addition to funding from the Ford Foundation.

Perhaps paradoxically, the struggles over the meaning and practice of fair trade have reenergized the advocacy community in its attempts to spread the message that "fair trade is a movement not a market". However, in reality fair trade is both a movement and a market. The tension between these two domains reflects an ambiguity at the center of fair trade in the United States resulting from long-standing debates within the contemporary movement - between those who view fair trade as primarily providing a shaped advantage by assisting poor producers to participate in global markets vs. those who understand it to be an alternative to the neoliberal market model (see Fridell 2007). In practice, this ideological division produces a struggle between companies that offer a small number of fair trade products aside a vast number of conventional items, and those that sell only fair trade certified products. It is also clearly evidenced in fair trade movement politics, which have been highly contested since FTUSA's unilateral decision to focus on fair trade quantity over quality (as the organization's critics framed the decision to leave FLO). The division also shapes the experience of on-the-ground fair trade advocacy work, and in this article I explore three arenas in which this is most clearly evidenced. First, as Sylvia explains in the interview quote above, some fair trade advocates are wary of FTUSA's power and strategies. They are aware that multiple fair trade certification frameworks currently exist; however they aren't always sure which ones are most desirable and why. This confusion can be problematic in Fair Trade Towns (FTT) advocacy work which involves convincing community members, institutions and governments to purchase more fair trade products. Second, in light of FTUSA's strategic marketization of fair trade and the entry of large corporate players into the U.S. fair trade market, fair trade advocates increasingly find themselves in the equivocal position of providing free labor and marketing for large corporations. Third, the efforts of some FTT advocates are stymied by the determined 'localvores' in their community who are more focused on minimizing carbon footprints and supporting local farmers than promoting social justice and environmental stewardship in the developing world. This tension raises important questions about the scalar politics of alternative markets and diverse economies.

In 2011 I began to explore the ways in which fair trade advocates and retailers are collaborating to "grow the fair trade market" one community at a time, through participation and ethnographic research in these local movements that bring together schools, places of worship, retailers and community organizations. The movement serves as a platform for community organizing and identity-building centered on international justice and alternative forms of economic exchange. As a member of the Fair Trade Lexington, KY steering committee and an active participant in fair trade promotional efforts on my campus, I became frustrated at our

\footnotetext{
${ }^{3}$ http://www.bloomberg.com/news/2011-11-03/u-s-rebel-s-split-riles-6-billion-world-of-ethical-commerce.html (accessed $12 / 10 / 11)$.
} 
inability to gain traction in the local community and initiated a project to investigate successful FTT campaigns in order to develop a blueprint for success. However, the recent developments in the US fair trade movement forced me to explore my own complex and sometimes contradictory perspectives on fair trade advocacy. My past research (Lyon 2011) critically explored the nature of producer and consumer relations in certified commodity networks and questioned the promise that fair trade and other consumption based development initiatives hold for agricultural smallholders in developing countries. Consequently, I have long understood that fair trade is no panacea for global inequalities and environmental degradation. However, I firmly believe that fair trade's single most important limitation is its small market size, which restricts its ability to improve the lives of the world's nearly five hundred million small farmers while fostering environmentally sustainable development.

In this article I employ Gibson-Graham's ontological reframing of the economy (2006) to think through fair trade's moral ambiguity. Their "diverse economies" perspective repoliticizes the economy by challenging the representation of capitalism as the necessarily and naturally dominant form (or identity) of economy (p.54). This theoretical repoliticization parallels similar, on-the-ground debates within alternative economic movements such as fair trade. Gibson-Graham's anticapitalocentric framework (p.72) recognizes that economic sectors, enterprises and subjects occupy multiple sites in the diverse economy and each of these sites has the potential to offer one or more economic identities. This is particularly relevant for the fair trade movement advocates described in this paper who, while primarily identifying as consumers, can also be viewed as producers whose volunteer labor is helping to create new economic possibilities in their own community. Gibson-Graham acknowledge, however, that economic dynamics are overdetermined and the relationship between activities in different sites cannot be predicted, but is open to politics and other contingencies. Consequently, while in certain situations individuals might fluidly and easily occupy multiple economic identities, in other instances subjects might experience uncertainties and ambiguities such as the ones explored here. Finally, for my present purposes a key component of Gibson-Graham's anticapitalocentric perspective is their admission that capitalist enterprise is as diverse as noncapitalist enterprise. Within the current fair trade movement it is this very diversity that is generating productive tensions.

Gibson-Graham's reframing suggests different sites for political action and organizing (Burke and Shear 2014). For example, examining the current tensions within the fair trade movement through the lens of diverse economies makes clear that while some political commitments, including the exclusive focus on small farmer cooperatives, are potentially threatened by the tensions in the fair trade movement outlined above, while others are encouraged, such as a heightened engagement with economic development in consumers' own local economies. Through consumer research, interviews with FTT campaign leaders and participation in organizing webinars, conference calls, and national and international FTT conferences I've come to better understand the ways in which this emergent consumer movement works to establish the "place" of consumption through a combination of social practice and "ethical selving" and, conversely, how consumption itself helps construct the meaning and lived reality of place. ${ }^{4}$ Place is not a natural, static, or given condition, but is instead a product of social relationships, actions, and political struggles (West 2005:633). The construction of place is always intertwined with power relations in complex ways (Zhang 2006) and anthropologists such as Elyachar (2005) have illustrated the deep sociality of place by showing how the production of different market forms can lead to radically different experiences and understandings of place. In privileging the "community of consumers and citizens" as 'directors' of the economy I am building on the work of the Webbs, early $20^{\text {th }}$ century proponents of consumer cooperatives, who configured consumption differently from the mainstream socialist tradition (Webb and Webb 1921:482). They understood consumption to be the creation of a type of life, writing: "In the social organization of the world, the act of consumption 'is directive: it is constructive"' (1921:482-3). Fair trade is essentially a method for

\footnotetext{
${ }^{4}$ Building on the work of Varul (2009) I understand "ethical selving" to be a response to individual freedom (Foucault 1987:117) in a culture of choice where the burden of constructing a consistent character is on the individual (Varul 2009:184; 2008). In a study of fair trade consumerism Varul and Wilson-Kovacs identify two forms of ethical selving, both aligning with Bourdieu's (1979) theories of taste. The "taste for ethics" describes individuals truly committed to consistent ethical consumption whereas "ethical taste" combines the moral and aesthetic judgments of more passive shoppers.
} 
systematically distributing social and economic surplus across transnational borders and, as Gibson-Graham point out, how surplus is distributed and allocated distills to a form of class politics. They explain, "Each new way of producing, appropriating and distributing or allocating social surplus allows for new becomings, new ways of being" (2003:138).

Common fair trade narratives are rooted in geographies of difference, and conceptualize place solely in relation to producer communities and identities located in specific spaces and represented through photographs and sound-bites. In contrast, the Towns campaign attempts to embed fair trade consumption in local places--a critical turn in the fair trade movement which opens up a politics of possibility for the promotion of alternative economic practices. The "politics of re-location" (Guthman 2004:235) at the heart of the Fair Trade Towns advocacy moves beyond the primary goal of most third-party certification systems, which is to reconnect commodities, their producers, and their locations of origin in the minds of consumers, by encouraging consumers to think critically about the communities where they themselves live. It serves to remind us that especially within the scalar spatial configurations of fair trade markets, social life remains "...placed and situated and engaging place is essential to maintain the process of life itself" (Swyngedouw 1997:141). In other words, the so-called global economy is, in essence, constituted by a multitude of diverse community economies and it is useful for academics and advocates to conceptualize the fair trade movement as creating mutually beneficial, multi-stranded links between these economies rather than simply understanding it as a mechanism for wealthy consumers to assist disadvantaged producers. This reframing of fair trade is consistent with Gibson-Graham's description of "place as a site of becoming, and as the ground of a global politics of local transformations" (2006: xxvii).

Simultaneously, this localization of fair trade consumption through the FTT movement furthers critical dialogue and new opportunities for reframing fair trade discourse and practices. Participation in Fair Trade Towns campaigns encourages advocates like Sylvia to stake a proprietary claim over the future of the fair trade movement in the United States by making demands on the certifying agencies, including FTUSA. The critical dialogue currently occurring within the fair trade movement encourages advocates to assess their own commitment to fair trade-rather than unquestioningly supporting a singular fair trade label, we must now work to understand the movement's complexity and influence its politics. Ultimately, the dynamics involved in Fair Trade Town movements may serve as a way for critics of FTUSA to fight against the movement's cooptation by large-scale corporate interests. In turn, it can generate forms of practical action at the local level, beyond individual acts of consumption, which can potentially scale up to form part of a larger, multi-faceted alternative economy. This process serves as an important reminder that while it is certainly true that consumerist campaigns such as fair trade are not "...pure, neutral vessels but bring to bear and mobilize political traditions and value systems that favor certain identities and relationships" (Trentmann 2007:1086), these identities and relationships are not fixed and can indeed be transformed through collective effort.

\section{Fair trade towns}

Fair trade is a form of alternative trade that seeks to improve the position of disempowered small producers by turning trade into a means of development. The movement, which promotes labeling, certification and consumer action, rejects the narrow view of Third World producers as victims and instead emphasizes the role that Northern consumption can play in their economic empowerment and well-being (Lyon 2011). Fair trade products on the whole still represent a minor share of the U.S. market, currently about US $\$ 1.4$ billion, however the retail value of fair trade sales has steadily increased over the past decade. In 2011 community-development premium payments resulting from U.S. imports reached a new high of US\$22 million (an increase of 50\% from 2010) (FTUSA 2011). ${ }^{5}$ Despite this apparent market strength, research indicates that in order to further extend the benefits of fair trade to disadvantaged producers, the market needs

\footnotetext{
${ }^{5}$ This figure actually represents the amount of Fair Trade USA certified products sold in the United States, an estimated $90 \%$ of the total fair trade market, which also includes alternative certifications, such as Fairtrade International, IMO Fair for Life, and Fair Trade Federation in addition to self-certification, such as that practiced by the Madison, WI cooperative coffee roaster Just Coffee.
} 
to grow substantially in the coming years (Lyon 2011). Therefore, despite his demonization, FTUSA's CEO's goal of doubling fair trade sales in the United States by 2015 is worthwhile if not imperative.

Fair Trade Towns USA is a grassroots campaign to "grow the fair trade market" one community at a time. ${ }^{6}$ The campaign is based on principles and guidelines set forth by Fairtrade Towns in the United Kingdom, where the first Fair Trade Town was recognized in 2000 (FTT 2010a). The US campaign began in 2005 with the first declared Fair Trade Town in Media, PA and was formalized in 2007 with the support of Fair Trade USA, Lutheran World Relief and Oxfam America who initially funded the coordinators, the website, and the development of organizing toolkits (FTT 2010a). The Fair Trade Towns USA campaign seeks to empower communities to organize a local grassroots movement for fair trade that brings together schools, places of worship, government offices, retailers and community organizations. Much as fair trade works to increase the incomes of small producers through alternative trade, advocacy movements such as this work to empower consumers by transforming international trade into a mechanism for community development at home. In other words the FTT campaign encourages consumers to use market exchange to reimagine their place according to a different, more ethical, developmental logic. As such the FTT campaign represents a qualitatively different turn in the fair trade movement, and is an interesting demonstration of how exchange implicates both producers and consumer communities. While the FTT campaign is primarily about growing the fair trade market, like the Fairtrade Fortnight campaign in the U.K. it offers the chance for fair trade supporters to enjoy themselves and "to feel part of a bigger movement at the same time as reinforcing their commitment to Fairtrade within their social networks" (Wheeler 2011a:8). In other words, the identity of the "consumer" is mobilized by the FTT campaign in order to "make available for people various 'pathways to participation' into forms of collective action which are motivated by much 'thicker' forms of identification: as good Christians, as Trade Unionists, as professionals, as members of solidarity networks, as environmentalists, or as residents of particular places" (Clarke et al. 2007a:245).

The goal of achieving the FTT designation is to provide a permanent platform for continued outreach and education to build the fair trade movement locally and deepen each community's commitment to international justice (FTT 2010b). In order to achieve FTT status a local steering committee must form and meet regularly, fair trade products must be used by a number of local organizations (churches, schools, hospitals, offices etc.), a range of fair trade products must be sold in retail establishments, and the town or city council must pass a resolution supporting fair trade and commit to serving fair trade products at its meetings (FTT 2010b). ${ }^{7}$ There are currently 30 Fair Trade Towns in the U.S. with many more campaigns in progress. These requirements are intended to be symbolic and material forms of activism. They form the basis of the FTT campaign because they are effective tools for publicizing the fair trade message and generating selfreflexivity regarding consumption habits. However, the fair trade movement can only rely so much on individual consumer choice: in order to double the fair trade market size by 2015 FTUSA will need to dramatically increase institutional fair trade purchasing. As Billy Goldsmith, the fair trade campaigns national coordinator, pointed out at a conference in October 2012, as a consumer he "only buy(s) coffee as he needs it, one pound at a time". Governments, churches, schools and other institutions on the other hand purchase hundreds of pounds/kgs. (or more) a year. ${ }^{8}$

In some ways, Fair Trade USA is playing catch-up in its promotion of Fair Trade Towns. Unlike in the U.K. and other European countries, the growth of fair trade markets in the United States over the past decade was driven primarily through FTUSA's efforts to lobby businesses to buy into the model (however, it is important to note that the fair trade market in the U.S. predates the formation of FTUSA and early leaders such as Equal Exchange laid the groundwork for its later success). The organization focused on expanding the supply of fair trade products in the mainstream retail markets rather than on building grassroots consumer

\footnotetext{
${ }^{6}$ See http://www.fairtradetownsusa.org for more information.

${ }^{7}$ At the Fair Trade Towns conference in October 2012 the campaign leader announced that they intend to amend this last criterion so that those communities with particularly recalcitrant town councils can still achieve Fair Trade Town status.

${ }^{8}$ For example, SODEXO, a corporation providing food services for universities, hospitals, military bases, conference centers, school districts and other institutions around the world purchases over 10 million pounds (4.5m kilos) of coffee each year for its U.S. clients alone. http://www.sodexousa.com/usen/newsroom/press/press10/earthdayaspretto.asp accessed October 31, 2012.
} 
support. In this way, fair trade has been less a consumer-led movement than a consumer-dependent one (Goodman 2004).

The current struggles over the future of fair trade in the United States, detailed below, can be read as a grassroots attempt to reclaim this alternative market from what some maintain is a corporate-led strategy of manufacturing desire, albeit a different kind of desire. Clearly, this tension between grassroots fair trade organizing and market-friendly approaches shapes the political import of fair trade as a sphere of ethical decision-making and raises an important question: can a desire for ethical choices that enable consumers to move beyond a decision making framework rooted in rational self-interest be manufactured by corporate campaigns? The answer to this question lies, at least partially, in the recognition that there is a large diversity of fair trade practices co-existing, at times uneasily, within this larger movement. Some forms of fair trade are comfortable bedfellows with capitalism and the extraction of surplus. Others, however, are more diverse and promote cooperation, mutualistic practices and social investment rather than extraction. This reading of fair trade is "an ethical practice of weak theory" ${ }^{9}$ in which we understand fair trade not as being limited and shaped by the capitalist world order, "but instead as the complex, surprising, unfinished outcome of innumerable contingent acts and decisions" (Gibson-Graham 2006:103). Fair trade transactions may continue to be embedded in the larger capitalist market in the years to come. However, Fair Trade Towns USA will hopefully also continue to localize fair trade within diverse economies across the United States, and in the process encourage participants to engage in collective ethical deliberation about the diverse meanings and goals of the larger movement.

\section{The politics of scale within the fair trade movement}

The debate over fair trade mainstreaming has been simmering for over a decade. Since shortly after FTUSA's founding scholars have argued that mainstreaming contradicts the fair trade movement's philosophical foundations (Marsden et al. 2000; Raynolds 2002; Renard 2003; Wilkinson and Mascarenhas 2007). Jaffee (2010:274) identifies five key points of dissent in the fair trade movement:

(1) the distinction between "movement-oriented" and "market-oriented" fair trade retailers;

(2) the relationship of FTUSA to these two groups of licensees;

(3) the level of fair trade minimum prices;

(4) the increasing certification of plantation agriculture and

(5) issues of fairness among the various actors in the supply chain.

While the fair trade movement's history stretches decades into the past, with the development of the fair trade certification system and label fair trade products began moving into mainstream retail outlets in the 1990 's. This process opened the door for large corporations to certify a small percentage of their products as fair trade in direct contrast to the tradition of $100 \%$ fair trade companies, such as Equal Exchange. Movement activists and scholars became increasingly concerned about cooptation-as Doherty explains, once MNC's like Sara Lee, Dole, Walmart and Nestle enter the market there are significant implications for the fair trade social movement because there are now licensees with greater power, capital and influence than fair trade organizations, which "leaves fair trade authorities in a weak position and lowers their bargaining power" (Doherty et al. 2012:16).

Fair Trade USA is a "robust" 501(c)(3) organization working with 750 companies including Starbucks, Costco, Sam's Club, Whole Foods, Ben \& Jerry's, and Green Mountain Coffee Roasters (Sherman 2012). Green Mountain Coffee Roasters bought 26 million pounds $(11.8 \mathrm{~m} \mathrm{~kg})$ of fair trade coffee in 2010 and paid US\$1.5 million in licensing fees to FTUSA, making it the nonprofit's largest source of revenue according to

\footnotetext{
${ }^{9}$ Weak Theory takes the form of an "economic language that cannot be subsumed to existing ways of thinking economy, and instead signals the ever-present possibility of remaking economy in alternative terms." [Gibson-Graham 2006: xxxiv].
} 
federal tax filings (Neuman 2011). When FTUSA announced its "Fair Trade for All"10 strategy in 2011 the organization's critics, such as Equal Exchange, argued that the organization's plan emphasized "quantity over quality" and "breadth over depth"—a vision in which "vast numbers of products throughout the grocery store could be certified fair trade in as fast a manner as possible" (Equal Exchange 2012a). In a rare business to business plea, Equal Exchange published a full page advertisement in the Burlington (VT) Free Press on May $20^{\text {th }} 2012$ encouraging the multi-billion dollar corporation GMCR to withdraw its support from the agency (Equal Exchange 2012b). They also circulated a petition in support of "authentic fair trade" which garnered more than 8,000 signatures and support from 550 organizations (Sherman 2012). In addition to such highly public criticism, a group of fair trade stakeholders (led by those largely opposed to FTUSA) convened in May of 2012 with four stated goals: to define fair trade and the fair trade movement (what they are and what they are not), organize the North American fair trade movement under a coordinated infrastructure with a common vision, reach agreement on a plan for cooperation and accountability within the movement, and develop a clear external message for the movement. ${ }^{11}$ While many industry leaders attended the meeting, fair trade advocates, including some members of FTT campaigns, were also present.

In a May 2012 interview Rice depicted the fair trade movement as hostile to innovation, asking "don't we want to democratize fair trade? Don't we want fair trade to be more than a white, middle-class movement?" (Sherman 2012). While fair trade movement leaders publicly question who has the right to "innovate" the fair trade movement, ${ }^{12}$ some acknowledge that the ensuing debate has been energizing. For example, fair trade advocate David Ransom published an article exploring the dissent and questioned whether "the principle purpose of fair trade (is) to change world trade; or will world trade change the principles of fair trade" (Ransom 2012). In the public comments section the highly critical Equal Exchange founder Rodney North points out:

...the very strong public response to the current controversy reminds (us) how much people care; this debate has caused thousands to actually stop and think about what 'fair trade' is. For too long to (sic) many just looked for the sticker without really understanding what fair trade was, is, or could be. Now they're learning.

Similarly, Jackie DeCarlo, from Catholic Relief Services Fair Trade, responded "Progress often comes through disruptive change, and it also can come through a humble search for the common good. We don't have to declare a right way or a wrong way" (Ransom 2012). There are fair trade scholars who also support fair trade mainstreaming, believing that it expands awareness for fair trade products and principles, reinforces fair trade campaigns and raises public demand for its products (Mohan 2010:44; Tallontire and Vorley 2005).

The fair trade movement in the United States remains in a state of flux. FTUSA is piloting its fair trade coffee plantation certification with a pilot program at the Fazenda Nossa Senhora de Fatima, a family-owned and operated farm in the Cerrado Region in Minas Gerais, Brazil. ${ }^{13}$ While it's clear that the fight for ownership of fair trade has energized the movement and market leaders, it has left Fair Trade Town campaign leaders in the tenuous position of explaining a complex and changing certification system to sometimes skeptical consumers. At present it is unclear how public criticisms of cooptation by movement activists shape consumer perceptions of fair trade. Jeff Goldman, executive director of the independent nonprofit Fair Trade Resource Network admits that the current "confusion does feel a bit frustrating. It gets very hard to explain what fair trade is when there are many different versions of fair trade and they all have different parts" (Leif 2012:18).

\footnotetext{
${ }^{10}$ See http://fairtradeforall.com for more information.

11 See http://www.fairtraderesource.org/2012/09/07/initiative-to-organize-the-n-america-fair-trade-movement-announcesnext-steps/ accessed November 4, 2012.

${ }^{12}$ For example, Jonathan Rosenthal, a co-founder of Equal Exchange wrote, "If you choose to look at who is making this decision to radically change the imperfect tool called fair trade, you might admit that it is nearly totally driven by wellintentioned white folks in the US with lots of money and big dreams...this feels like a move right out of the colonial playbook" (Sherman 2012).

${ }^{13}$ See http://fairtradeforall.com/coffee-pilots-in-brazil/ for more information.
} 
At the Fair Trade Towns and Fair Trade Universities conference in October 2012 there was no official mention of the controversy in the program and planned sessions. However, when attendees raised their concerns in the plenary sessions they were addressed by the panelists. For example, Jackie De Carlo, of Catholic Relief Services Fair Trade, said at one point, "...fair trade is not perfect but if we look with a clear eye towards its imperfections that will help us with credibility down the line." A FTUSA consultant, Steven Honeyman, followed up saying "...let's not agonize, let's organize. We tend to talk to each other. It's now time to step outside ourselves and talk to others." Participants also eagerly discussed their concerns amongst themselves. They sought out information from one another about the current status of different fair trade initiatives and traded opinions and viewpoints during the question and answer sections of breakout sessions and informal conversations.

The most forthright discussion of the controversy I witnessed at the conference occurred in a breakout session on the topic of what to focus on once a Fair Trade Town has declared itself. In an assessment of her city's campaign strengths and weaknesses one of the session organizers identified the following as threats:

(1) FTUSA's non-transparent decisions and related consequences,

(2) the fact that FTT campaigns aren't independent from FTUSA,

(3) a lack of interest in political action to effect change both within the movement and FTUSA,

(4) and a lack of dialog about controversies.

A conversation among session participants ensued over why these should be viewed as threats. One representative from a campaign in progress said, "People don't really know what is going on and they think fair trade is bad when they're really talking about Fair Trade USA. They're confused. 'Oh, so is Equal Exchange not fair trade anymore?' We're all trying to give consumers confidence in the fair trade system and it's discouraging." The other session leader acknowledged:

I think there is general criticism from the public and that has changed and challenged some of our (meaning his Fair Trade Town campaign's) primary messaging. This is related to the higher understanding and brand awareness of fair trade in our city and it leaves some consumers lacking confidence in the fair trade movement.

A concern that was repeatedly voiced in informal conversations and public forums at the conference is the fact that the Fair Trade Towns national campaign is currently housed within FTUSA. A member of the FTT national steering committee explained that they have decided to continue to be housed within FTUSA but that the campaign isn't "owned" by FTUSA. This Memorandum of Agreement was reportedly negotiated for 3-5 years. In a plenary session an audience member asked anonymously for the panelists to clarify the relationship between the FTT campaigns, FTUSA and sponsors like GMCR. One responded that "it is a big tent movement that includes lots of different people in the fair trade world and not just one entity. It takes money to run programs like this and for the last 3-4 years FTUSA has raised money to support the campaigns". Echoing this concern, in a later session an audience member questioned why the Fair Trade Towns national campaign leaders had FTUSA e-mail addresses if the two entities were actually separate. Based on my conversations with several Fair Trade Towns campaign leaders and my own experience FTUSA's symbolic, if not actual, ownership of the FTT movement can prove problematic at the local level. Our own campaign stalled when steering committee members questioned whether moving forward with our efforts would be an implicit vote of support for FTUSA's controversial decisions.

The ongoing productive debate following FTUSA's controversial decision is a reminder that diverse economies are not inherently noble and pure, but instead are occasionally subject to the same dissent and disillusion that characterize market economies. Gudeman defines fair trade as a "dialectical movement that embodies economy's tension": it promotes standard economics by supporting markets but increases prices and product information for the consumer to promote mutuality with the original producer (2008:113). In 
disputing the path forward, fair trade leaders and on the ground advocates are renewing the fair trade community, in the sense of an imagined or global grouping that never meets yet holds interests in common (Anderson 1983). The disagreements detailed above reinforce fair trade's mutuality among Northern participants as much as the community's shared language, speech codes, norms, and social agreements do.

\section{Debating the role of corporate retailers}

Paying attention to emergent economic possibilities does not mean that we should shy away from exploring the diverse forms of power that influence the relationships between different economic practices (Gibson-Graham 2006:71). In the case of the Fair Trade Towns campaigns an exploration of power relations reveals a complex, moral ambiguity at the heart of a movement which essentially promotes social change through consumption and the growth of a fair trade retail market which is increasingly dominated by large corporate actors and national chains.

I first encountered this ambiguity in 2011 when I began to create a list of fair trade retailers in my city. For a city the size of Lexington, Fair Trade Towns status requires a minimum of 30 retailers offering at least two fair trade products. In order to reach this number I was forced to include corporate retailers, such as Kroger, Whole Foods, Starbucks, and Fresh Market on our list. While I strategically placed them at the bottom underneath locally owned businesses, the reality is that there are only a handful of local retailers offering fair trade products so we are essentially forced to offer free advertising for large chains. Jaffee and Howard speak to this in their assessment that the fair trade movement has subsidized the market and corporate actors have reaped profits from exploiting the niches "painstakingly built by grassroots activist(s)" (2010). And yet, at the same time, I struggle with an internal dialogue that I know is familiar to other fair trade advocates: while I don't agree with many of their politics, I appreciate that when corporate giants such as Walmart offer fair trade products they provide working class people and suburban dwellers with an opportunity to participate in this campaign of reimagining our place through the lens of fairness. If we build our community economy solely around downtown restaurants serving local kohlrabi and US\$20 a plate pasture fed beef, what kind of a community is it? Who does it exclude? What, ultimately, are the goals of achieving Fair Trade Towns status?

At the national conference in 2012 it was clear that many participants also struggled with these same questions. At one session which provided advocates a chance to learn more about Green Mountain Coffee Roasters' fair trade purchasing and the corporation's involvement in fair trade consumer campaigns a longtime Fair Trade Town organizer stated quite simply, "We're a free workforce for you so you should be supporting conferences like this." This was certainly the case with the introduction of Cafedirect's fair trade coffee in the U.K. in the 1990s which relied heavily on "the availability of free human capital; Cafedirect's founders mobilized supporters to persuade supermarkets to stock the products" (Wright 2004: 666). In a plenary session at the national conference one participant asked the panelists whether there was any way to positively impact fair trade without "buying more stuff?" The panel included three fair trade producer representatives: one, a manager from a fair trade banana cooperative in Ecuador responded, "No, I don't think so because money makes the world go round." The chief impact officer of FTUSA replied, "It's not about buying more. It's about buying differently." This consumer dilemma is reflective of fair trade's status as a quintessentially postmodern social movement-in the words of Moberg, "one that is private, consumption-based and overwhelmingly market-driven" (2008:179). As he and others have argued, the efforts of fair trade promotional campaigns essentially boil down to a singular purpose: encouraging greater purchases of fair trade branded items.

Increasingly, scholars are challenging the notion that fair trade consumer campaigns are primarily about influencing self-reflexive, rational economic actors. First, consumers do not necessarily practice what activists preach—as Trentmann points out, "The language of the 'critical consumer' caring about distant others may be campaign language rather than an identity in practice" (Trentmann 2007:1081; cf Wheeler 2011:13). The development of fair trade consumption does not aim simply to enroll people as consumers but rather to address them as members of varied social networks who will not only consume ethically but also initiate discussion with friends, family, co-workers and others (Clarke et al. 2007b: 593). Therefore, it is useful to 
think about the fair trade consumer not as an individual but rather as a "person-in-community": it is through our mutual affiliations that we constitute aspects of our identities (Gudeman 2008:32). Furthermore, people who engage actively with fair trade consumption activities do not do so solely by recognizing themselves as consumers but instead "use consumption practices to express existing commitments to various ethical and political projects" (Clarke et al. 2007b:594).

Ethical shopping can be a force for progressive change but it also can be a zone of "contradictory consumption" (Littler 2011:28) constituted through a battery of different practices which at times conflict with one another. While fair trade's mainstreaming in the United States has certainly made the movement less pure, it has also significantly broadened consumer access to these ethical alternatives. The mainstreaming of fair trade and the growing prominence of FTT campaigns in the United States suggests that communities are forming around ethical deliberation about the economy and that pre-existing local economic politics and economic conditions (such as a retail environment dominated by corporate retailers) are forcing local fair trade movements to adopt broader political platforms that extend beyond the creation of ethical consumers and private, consumption-based activism. As explored below, in rooting fair trade consumption in particular places, the movement becomes about more than simply increasing fair trade sales. The politics of re-location certainly heighten attention to the economic realities of global supply chains but they also spark debate over economic justice and alternatives to capitalism within consumers' own communities.

\section{Localizing fair trade}

In the process of initiating and maintaining a Fair Trade Towns campaign participants often confront multiple and disparate understandings of the concepts "local" and "fair". The first hurdle a FTT campaign has to pass is forming a steering committee. Our campaign in Lexington was initiated by Trudy, a fair trade importer and retailer who is an active community member. Trudy invited Robin, a local social justice activist, to one of our first meetings at a local fair trade coffee shop. About twenty minutes into our conversation Robin loudly interjected, "I just don't get it. I don't understand why we should be investing all of this energy in supporting small farmers in Latin America and Africa when the farmers here in our own backyard are struggling." In response I stammered, "Well no matter how hard they try local farmers aren't going to be able to grow coffee." Later, I mentioned this experience to one of my research participants, a fair trade importer turned academic who spearheaded a FTT campaign in a small Vermont town. Karen explained how she had gone around to the local businesses to try and get them to sell fair trade products and they repeatedly told her they weren't interested. The campaign only took off once she began promoting the message "Buy local and when you can't buy local buy fair."

This has also occurred in other FTT campaigns in communities with pre-existing buy local movements and well-supported regional food networks-in these cases fair trade objectives had to be folded into campaigns to support local farmers and businesses (Malpass et al. 2007). For example, the Northampton, Massachusetts "Buy Local/Buy Fair Resolution" (passed March 20, 2008) ${ }^{14}$ established a policy to "maximize purchase of locally produced Fair Trade Certified, and/or fairly traded products from locally owned businesses in the process of procuring necessary goods for municipal operations". As a member of that city's campaign relayed at the FTT conference in 2012, "the buy local, buy fair message is a very inclusive message: to embrace local farmers but also to embrace small farmers around the world."

Despite the efforts of FTT campaign leaders to link their message and efforts with buy local activists, some face ongoing challenges. The topic was raised multiple times at the FTT conference as campaign members strategized about how to build partnerships in their communities. For example, one campaign member from a city with a strong buy-local movement explained that she is frustrated by local activists "who would rather support a local chocolate company than a fair trade one". Another said that they are "experiencing push back from hard core localists who say the (fair trade) carbon footprint is too big...but are they giving up coffee, tea and sugar?" Participants offered possible solutions to one another: one campaign member explained that after struggling to gain traction with the buy local movement in her city they

\footnotetext{
14 The resolution is available at http://www.northamptonma.gov/economicdevelopment/Buy Local Buy Fair, accessed November 2, 2012.
} 
"...piggybacked on the slow food and slow fashion movements because not everything can be produced here." Campaign members from other cities mentioned the carbon offsets available for fair trade purchases and the fact that "fair trade can be actionable" for sustainability initiatives in local governments. One campaign member explained that she chooses to connect fair trade to the larger environmental movement: "I now start with the big picture of our planet and sustainability whereas before I would start with the fair wage issue. I link it back to global climate change."

As part of our fair trade organizing efforts on campus I worked with two students to conduct research on university students in order to explore their shopping habits and understandings of fair trade in the Spring of 2012. The research involved an online survey of 185 students and extended participant observation and semi-structured interviews with 9 participants (Lyon et al. 2014). The interviews probed students' thoughts about the overlapping or contradictory goals of buy local and fair trade campaigns. Interestingly, like the FTT advocates, our participants viewed these as complimentary, rather than competitive, ideals. Julia's thoughts encapsulated those of several of the students:

I think...there probably is the potential for the two of them to butt heads, and in some cases the local food movement is good in helping out local farmers and keeping economies strong because we know from the past that pouring money into a Kroger or a Walmart really doesn't help the local economy at all...but at the same time people are always going to want coffee. And so that system can be more fair, and we can create schools and help people who are supplying that coffee. So yeah, I think there's the potential for some contention between the two movements, but I think that there's also a way to work them both hand in hand so that everybody...can be happy.

Another student, Bethany, articulated a point that was repeatedly made by FTT advocates - that the farmers producing fair trade products live in small "local" communities just like the one we live in:

When I think of fair trade...I guess I feel like it's an organization that buys products made from local communities from other countries at a fair price so they aren't getting gypped out of anything and it's stimulating the local economy too, it's allowing them to work without...an NGO going in and giving them money.

At the FTT conference FTUSA's Chief Impact Officer referred to fair trade as "a farmer's market gone global...sometimes if you talk about transportation miles it doesn't fit but if you're talking about knowing your product and your producer then it does fit." This concept of a global farmers market and the acknowledgement that there are farmers worthy of support in local communities everywhere reflects the fact that the concept of "local" food systems can be difficult to pin down, "much less cordon off within a globalized food system" (Allen and Hinrichs 2008: 343). Scale is a fundamentally relational concept that can only exist in relation to other larger and smaller scales (Born and Purcell 2006).

'Buy Local' advocates frame the "local" as the space where "ethical norms and values can flourish" so that localism becomes synonymous with the rise of alternative and more sustainable food networks (Du Puis and Goodman 2005:359). However, as food systems researchers consistently maintain there is nothing inherently just and sustainable about local production (Allen and Hinrichs 2008; Bellows and Hamm 2001; Born and Purcell 2006; Du Puis and Goodman 2005; Gray 2014; Guthman 2011). Guthman eloquently points out, "eating local, organic, seasonal food that you prepared yourself may be pleasurable but it is not universally so, nor is it tantamount to effecting social justice" (2011:5). As opposed to fair trade, issues related to labor, class and race in farming are often less fully incorporated into the politics of 'local food' (Weiss 2011:439).

Allen and Hinrichs suggest that "in order to bring social justice forward, Buy Local campaigns may need to reduce or relinquish their selective focus on 'local"' (2008:333). A concrete way to do this is through the inclusion of fair trade criteria and a concomitant shift in the focus of these campaigns from a politics of 
place to a politics in place. In other words, rather than a focus on proximity, politics in place is a "nonterritorial way of viewing place politics in an age of global connectivity. Instead of seeing political activity as unique, places might be seen as the sites which juxtapose the varied politics - the local, national, and global—that we find today" (Amin 2002:397 in Du Puis and Goodman 2005:364). Katz's concept of "critical counter-topographies" illuminates the possibilities of uniting local and fair trade concerns. She reminds us that one site:

Is connected analytically to other places along contour lines that represent not elevation but particular relations to a process (e.g., globalizing capitalist relations of production). This offers a multifaceted way of theorizing the connectedness of vastly different places made artifactually discrete by virtue of history and geography but which also reproduce themselves differently amidst the common political-economic and socio-cultural process they experience (Katz 2001:1229).

When fair trade is combined with buy local campaigns it serves as a potent reminder that poverty and privilege are co-dependent in the global capitalist system. It also raises the possibility for unique forms of transnational solidarity, for example, by fostering connectivity between local producers and consumers and fair trade producers and consumers in the developing world (Malpass et al. 2007:640). The Chicago Fair Trade campaign utilizes this scalar frame of place to bring diverse interests together in multiple projects. The campaign set a goal of ensuring that fair trade products are offered for sale in each of the city's 77 neighborhoods. However, as one of the campaign members relayed at the Fair Trade Towns conference "if you have food deserts in a big city guess what? You're going to have fair trade deserts too." As a result the campaign has worked to support cooperative grocers in lower income neighborhoods across the city and brought producers from places like Ghana to speak at retail outlets across the city, not just those in the privileged neighborhoods. They also collaborated with a NGO that works with Latino day laborers to develop Café Chicago, a cooperative of 8 immigrants trained in coffee roasting. In recognition that "fair food isn't just about fair trade food" the campaign offered local support to the Coalition of Immokalee Workers and their campaign to reform Florida's tomato industry. Finally, Fair Trade Chicago developed the "Project Fair Play" which uses soccer tournaments and fair trade soccer balls to educate Chicago schoolchildren about labor abuses and child workers in the Pakistani soccer ball industry. ${ }^{15}$

Each of these initiatives challenge the paradigm of economic development which views localities as subordinate economic identities and the economy as a global system or "container that determines the fate of all localities, whether they be multilateral trading blocs, nations, regions within nations, or municipalities" (Healy and Graham 2008). As ethical subjects, the members of Fair Trade Chicago are also performing community in a different way, acknowledging the importance of simply "being together in place" (GibsonGraham 2007:49).

Place is established through concrete experiential qualities and social practice (Lefebvre 1991 in Weiss 2011). FTT campaigns frame involvement around place specificity: these towns become known not only as places that promote fair trade but also as places characterized by fairness (Malpass et al. 2007:638). For example, the Northampton, MA "Buy Local/Buy Fair Resolution" explicitly states this:

Whereas, the City of Northampton, as a consumer, intends to be cognizant of the impact that our consumption has on the communities that produce the goods we purchase; and Whereas the City of Northampton intends that municipal funds are spent in an ethical manner and promote local economies both domestically and abroad whenever possible; and Whereas, Buy Local and Fair Trade campaigns are an innovative approach to commerce, the purpose of which is to provide consumers and businesses with the opportunity to make a positive, economic, social, and environmental impact local and in communities around the world.

\footnotetext{
15 See for more information, http://www.cleanclothes.org/documents/ILRF soccerball report.pdf and http://www.chicagofairtrade.org/jobs-with-justice/fairplay.html. Acccessed November 2, 2012.
} 
Gibson-Graham demonstrate how subjects "may shift and create new identities for themselves despite the seemingly hegemonic power of dominant discourses and governmental practices" (2006:24). In the same way, through collective social practice, places may adopt new aspirational identities that serve to repoliticize the economy by challenging the representation of capitalism as the dominant form (Gibson-Graham 2006:54). The combination of fair trade and buy local campaigns that FTT advocates support enables people to intentionally establish economic practices and relationships that are an alternative to corporate capitalism and business as usual.

\section{Conclusion}

At an analytical and practical level I have reached a place of involvement tempered by productive skepticism towards the Fair Trade Towns movement. Like many of my research participants, I am a bit cynical when it comes to FTUSA and their ambitious plans for market growth. At the same time, I remain committed to this process of reimagining my local place through the lens of ethical consumption and economic justice. I am encouraged by the fact that there is space within the movement for critical dialogue and that the ongoing debates are serving to reenergize the fair trade movement here in the United States. The historian Frank Trentmann convincingly demonstrates that fair trade has emerged from the soil of historically changing moral landscapes, including antislavery and cooperative movements, but also free trade and progressive ideas of global social justice. Therefore, "to conduct the debate about 'fair trade' in bipolar terms of markets versus morals is problematic and unhelpful" (2007:1097).

Rather than a revolutionary program to overthrow free trade, the fair trade movement could benefit from a Maussian framing as a form of social change which is "by no means committed to revolutionary or radical alternatives or brutal choices between two contradictory forms of society" but instead change which will be made through a process of building new groups and institutions alongside and on top of the old ones (Hart et al. 2010:8). This parallels Gibson-Graham's anti-capitalocentric reading of the diverse economy, in which there are many forms of alternative market transactions in which goods and services are exchanged and commensurability is socially negotiated and agreed upon (2006:62). Consequently, rather than making abstract appeals to radical economic transformations, localizing fair trade consumption may represent a concrete road to other economies based on the field of possibilities already open to us (Hart et al. 2010: 8). This is accomplished through a stronger linking of fair trade production and consumption, an expanded understanding of who benefits from fair trade (both producers and consumers) and a realignment of the social relations and identities created through fair trade.

The Fair Trade Towns movement is not fixated or limited by what "The Economy" will or will not allow; instead it represents only one of a number alternative economic practices and opportunities (Burke and Shear 2014; Healy and Graham 2008). As Gibson-Graham note, it is important to recognize "difference within the category of capitalist enterprise" and that alternative capitalist firms that distinguish themselves from their mainstream capitalist counterparts through a commitment to ethical practices in addition to profit making can play an important role in the diverse economy (2006:67). Reconsidering fair trade through this lens demonstrates that we do not need to choose between resisting or accommodating the demands of a global capitalist economy in order to strengthen local communities around the world.

\section{References}

Allen, P. and Hinrichs, C. 2008. Selective patronage and social justice: local food consumer campaigns in historical context. Journal of Agricultural and Environmental Ethics 21:329-352.

Anderson, B. 1983. Imagined communities: reflections on the origin and spread of nationalism. London: Verso.

Bellows, A. and Hamm, M. 2001. Local autonomy and sustainable development: testing import substitution in localizing food systems. Agriculture and Human Values 18:271-84.

Born, B. and Purcell, M. 2006. Avoiding the local trap: scale and food systems in planning research. Journal of Planning Education and Research 26:195-207. 
Burke B.J. and B.W. Shear. 2014. Introduction: engaged scholarship for non-capitalist political ecologies. Journal of Political Ecology 21: 127-144.

Clarke, N., C. Barnett, P. Cloke, and A. Malpass. 2007a. Globalizing the consumer: doing politics in an ethical register. Political Geography 26: 231-249.

Clarke, N., C. Barnet, P. Cloke and A. Malpass. 2007b. The political rationalities of fair-trade consumption in the United Kingdom. Politics and Society 35: 583-607.

Doherty, B., I.A. Davies, and S. Tranchell. 2012. Where now for fair trade? Business History 55(2): 37-41.

Du Puis, E.M. and D. Goodman. 2005. Should we go 'home' to eat? Toward a reflexive politics of localism. Journal of Rural Studies 21:359-371.

Elyachar, J. 2005. Markets of dispossession: NGOs, economic dispossession and the state in Cairo. Durham: Duke University Press.

Equal Exchange. 2012a. Background summary. January 2012. www.equalexchange.coop/small-farmer-campaign. Accessed October 30, 2012

Equal Exchange. 2012b. An open letter to Green Mountain Coffee Roasters from Equal Exchange. May 20, 2012. Press Release by Rodney North. www.equalexchange.coop/small-farmer-campaign Accessed October 30, 2012

FTUSA. 2011 Fair trade almanac. Available at http://fairtradeusa.org/sites/default/files/Almanac\%202011 pdf accessed October 23, 2012.

Fridell, G. 2007. Fair trade coffee: the prospects and pitfalls of market-driven social justice. Toronto: University of Toronto Press.

Gibson-Graham, J.K. 2003. Enabling ethical economies: cooperativism and class. Critical Sociology 29(2): 123-163.

Gibson-Graham, J.K. 2006. A postcapitalist politics. Minneapolis: University of Minnesota Press.

Goodman, M. 2004. Reading fair trade: political ecological imaginary and the moral economy of fair trade foods. Political Geography 23:891-915.

Gray, M. 2014. Labor and the locavore: the making of a comprehensive food ethic. Berkeley: University of California Press.

Gudeman, S. 2008. Economy's tension: the dialectics of community and market. New York: Berghahn Books.

Guthman, J. 2011. Weighing in: obesity, food justice, and the limits of capitalism. Berkeley: University of California Press.

Guthman, J. 2004. The 'organic commodity' and other anomalies in the politics of consumption. In A. Hughes and S. Reimer (eds.) Geographies of commodity chains. New York: Routledge. Pp. 233- 249.

Hart, K., J. Laville and A. Cattani: 2010. Building the human economy together. In Hart, K., J. Laville and A. Cattani (eds.) The human economy: a citizen's guide. New York: Polity Press. Pp. 1-17.

Healy, S. and J. Graham. 2008. Building community economies: a postcapitalist project of sustainable development. In D. Ruccio (ed.) Economic representations: academic and everyday. New York: Routledge. Pp. 291-314.

Hinrichs, C. and P.Allen. 2008. Selective patronage and social justice: local food consumer campaigns in historical context. Journal of Agricultural and Environmental Ethics 21:329-352.

Jaffee, D. 2010. Fair trade standards, corporate participation, and social movement responses in the United States. Journal of Business Ethics 92: 267-85.

Jaffee, D. and P. Howard. 2009. Corporate cooptation of organic and fair trade standards. Agriculture and Human Values 27(4): 387-99.

Katz, C. 2001. Vagabond capitalism and the necessity of social reproduction. Antipode 33(4): 709-728.

Leif, D. 2012. Issue of the year: the splintered state of fair-trade coffee. Coffee Almanac 18-20.

Littler, J. 2011. What's wrong with ethical consumption? In Lewis, T. and E. Potter (eds.) Ethical consumption: a critical introduction. Routledge: New York. Pp. 27-38. 
Lyon, S. 2011. Coffee and community: Maya farmers and fair trade markets. Boulder: University Press of Colorado.

Lyon, S., S. Ailshire and A. Sehon. 2014. Fair trade consumption and the limits to solidarity. Human Organization. Forthcoming.

Malpass, A., P. Cloke, C. Barnett and N. Clarke. 2007. Fairtrade urbanism? The politics of place beyond place in the Bristol Fairtrade City Campaign. International Journal of Urban and Regional Research. 31(3): 633-45.

Marsden, T., A. Flynn and M. Harrison. 2000. Consuming interests: the social provision of foods. London: UCL Press.

Moberg, M. 2008. Slipping away: banana politics and fair trade in the Eastern Caribbean. New York: Berghahn Books.

Mohan, S. 2010. Fair trade without the froth: a dispassionate economic analysis of 'fair trade'. London: The Institute of Economic Affairs.

Neuman, W. 2011. A question of fairness. New York Times November 23, 2011.

Ransom, D. 2012. Is it curtains for fair trade? New Internationalist blog. 9/12/2012

Raynolds, L. 2002. Consumer/producer links in fair trade coffee networks. Sociologia Ruralis 42(4): 404-424.

Renard, M. 2003. Fair trade: quality, market, and conventions. Journal of Rural Studies. 19:87-96.

Sherman, S. 2012. The brawl over fair trade coffee. The Nation August 22.

Swyngedouw, E. 1997. Neither global nor local: "glocalization" and the politics of scale. In Cox, K. (ed.) Spaces of globalization: reasserting the power of the local. New York: Guilford Press. Pp. 137-166.

Tallontire, A. and B. Vorley. 2005. Achieving fairness in trading between supermarkets and their agri-food supply chains. Briefing paper for the UK Food Group. Accessed 2014.

Trentmann, F. 2007. Before "fair trade": empire, free trade, and the moral economies of food in the modern world. Environment and Planning D: Society and Space 25: 1079-1102. draft

Varul, M. 2009. Ethical selving in cultural contexts: fairtrade consumption as an everyday ethical practice in the UK and Germany. International Journal of Consumer Studies 33: 183-189. draft

Weiss, B. 2011. Making pigs local: discerning the sensory character of place. Cultural Anthropology 26(3): 438-461.

West, P. 2005. Translation, value, and space: theorizing an ethnographic and engaged environmental anthropology. American Anthropologist 107 (4):632-642.

Wheeler, K. 2011. The practice of fairtrade support. Sociology 46(1): 126-141.

Wilkinson, J. and G. Mascarenhas. 2007. The making of the fair trade movement in the south: the Brazilian case. In Raynolds, L. D. Murphy, and J. Wilkinson (eds.) Fair trade: the challenges of transforming globalization. London: Routledge. Pp. 157-179.

Wright, L. and S. Heaton. 2006. Fair trade marketing: an exploration through qualitative research. Journal of Strategic Marketing 14:411-426.

Wright, C. 2004. Consuming lives, consuming landscapes: interpreting advertisements for Cafedirect coffees. Journal of International Development 16:665-680.

Zhang, L. 2006. Contesting spatial modernity in late Socialist China. Current Anthropology 47 (3): 461-484. 